\title{
Dutch Batik Motifs: The Role of The Ruler and The Dutch Bussinesman
}

\author{
Asidigisianti Surya Patria \\ Department of Design, Faculty of Languages and Arts, Universitas Negeri Surabaya, \\ Jl. Ketintang Baru XII No.34, Ketintang, Gayungan, Surabaya, Indonesia \\ E-mail: asidigisianti@yahoo.co.id
}

Received: October 1, 2016. Revised: December 4, 2016. Accepted: December 11, 2016

\begin{abstract}
Dutch Batik is the referent of batik which is made by European-Indo woman industry. It can be identified by the European pattern which is a bouquet. This research is aimed to describe the correlation between the development of Dutch Batik with the role of the Dutch government and the Dutch merchant. The library research was used during analyzing the role of the government and the merchant using the Talcott Parsons' functional structure theory. The batik Dutch companies were commercial oriented. It is different from real Javanese batik which had a purpose to be worn by themselves. Dutch Batik was the expression of the idea and behavior of the Dutch who lived in Indonesia. They expressed their western by using the patterns that were shown in their batik.
\end{abstract}

Keywords: Dutch Batik; motifs; businessman

How to Cite: Patria, A. S. (2016). Dutch Batik Motifs: The Role of The Ruler and The Dutch Bussinesman. Harmonia: Journal of Arts Research and Education, 16(2), 125-132. doi:http:/ / dx.doi.org/10.15294/harmonia.v16i2.7357

\section{INTRODUCTION}

Definition of Batik in Javanese Kromo means fiber and in Javanese Ngoko means to write, then it is interpreted as painting (dripping) wax. Famous ancient batik painted in simple lines and dots, and easily poured or dripped with a wax that is melted on the fabric (Susanto, 2002). Djoemena (1990) stated that Batik is included in the painting. The tools are used to paint is called 'canting' with a variety of sizes. It depends on the type and the fine lines or the desired of points. Batik art can be viewed from various aspects, such as the process of batik, the quality of batik, the motifs and color of batik. The canting itself is a small bowl made of copper which has a stout-stemmed bamboo or wood that can be filled with fluid wax as a material for painting.
H. Santosa Doellah, the founder of Batik Danar Hadi and a collector of Indonesian batik concluded that Batik is an ancient art technology that develops simultaneously along with the art of making the fabric itself. Batik has been developed in Indonesia since centuries ago, in the land of Java, batik has evolved into an expression that is rooted in mythology, philosophy, and the symbol of the human life cycle. From China and India came the influence of Hinduism and Buddhism, while the Arabs and Persians came the Islamic atmosphere. The trail was reflected in a variety of Batik motif on the north coast of the island of Java and the other hand, in Surakarta and Yogyakarta is the center of the aristocracy. Batik is a masterpiece that is influenced by the course of time and the changing environment.

Since the days of empire, Batik has 
been imposed by the royal leader (king) and the royal family. The motif that was used should not be applied by the commoners. This motif is called 'Larangan' (Prohibited) motif (not allowed), while the commoners may use other motives. Hereby we can see the profound meaning of the motif until only the king and the royal family is allowed to wear (Roojen, 1998). A royal era has passed, but the principles of the application of Batik motif still adhere. Although it is not prohibited from applying the $L a-$ rangan motifs to be worn outside the court but with some provisions.

Batik is an expression of identity and environment of the maker. The motif becomes the outpouring of both individual persons and community groups. Motifs can also describe goal against the ideal thing. Just as a cultural, motif can change that is affected by the development environment and the prevailing norms in society (Wardhani, 2004). Cirebon dominant motif like the waves of the sea is added the sea creatures, due to the geographical location of Cirebon that is located on the north coast of Java. In the region of Central Java, there are a lot of fruit and flowers, so that the resulting motif was not far from flowers and fruits (Dharsono, 2007, p. 69).

As a result of interaction with the times and historical circumstances, the motif is distinguished by patterns, and colors. Royal Batik combines Hindu and Javanese culture in the fifth century through the ornament eagle, dragon, lotus, and the tree of life and then combining with Islam distinctively diverse stylization of symbols but no animals. Chinese immigrants came later brought oriental ornaments such as: snakes, lions, dragons and bird phoenix by presenting in bright colors and pastel. When the Dutch colonial Dutch batik motifs appear erupted in 1840 and reached the peak in 1890 to 1910, the results of beginning the Dutch/European in the north coast of Java. Color and variety of motives distinctive individual styles present a unique and significant.

The rise and growth of culture cannot be separated from the character, distin- ctive features, and phenomena in the life of the community where the Batik was born. The formalization of shape, meaning the embodiment and the work was associated with the phenomenon of social, political, economic, cultural, and religions that developed in the community because they were massive forming exponent which has a set of uniform. The present of the work is influenced by both the natural surroundings and the used as raw materials and sources of inspiration. It will be difficult to make the resources and cultural roots whether the phenomenon of political, economic, social, and religious which from the work or even the work affected the phenomenon (Gustami, 2007, p. 233).

Dutch Batik as one of the forms of culture are objects that can be the result of cultural photographed and viewed (Koentjaningrat, 2009, p. 151). The motive in this paper will discuss the effect and influence of the Dutch colonial with Coastal Batik in Java. Although Batik in Java had been existed since ancient but with the arrival of the Dutch Batik changes. Batik itself also affected in the culture of Dutch people such as migrants, especially in the way they dress.

The beginning of the Dutch Batik could be traced back in the arriving of VOC (Verenigde Oost Indices Compagnie) which was the trading company owned by the Dutch government. Earlier the textile trading had been a monopoly of Indian then VOC tried to overcome and took over in 1677 (Veldehuisen, 1993, p. 19).

VOC's arrival also affected the development of batik in Java because it brought to the Netherlands to Indonesia and its customs and practices espoused though they came to trade or even trade monopoly. The Dutch people were settled in Indonesia, especially Java, not a month or two, but for years, considering the journey it has taken from the Netherlands by ship for months.

Before the Dutch came to Java, there have been patterned batik fabric mainly Mataram era, it was just a design motif that was used natural dyes and simple with color-warrants tend to be dark. But 
after Dutch traders brought dyes with new colors, Batik started to get significant changes in terms of color and design. Although the base before the Dutch came Batik Pesisir also used bright colors, but still used natural dyes. Artificial dyes from India from the Dutch trade increased the repertoire of colors in Batik.

There were two major batik styles of Java. First, In Central Java, where sultanates ruled the area, batiks were made in brown, blue, and black, combined with white and cream. Each motif applied to have symbols and meanings deep philosophy Many of the motifs were originally prohibited for commoners to wear. Batik Kraton (Royal Batik) tends to nuance orderly, but laden with values and spiritual significance and symbolism of the universe. For royal batik maker was a worship that embraces high art that follows the rules and philosophy of Javanese aristocracy palace (Ratyaningrum, 2005).

On the north coast, a whole different style of batik was developed under the influence of early trade connections along the coastline (Dartel, 2005, p. 12). The motif is an applicable naturalist and is influenced by foreign cultures seem to be strong, such as; Chinese and Arabic. Colors used more variety of color shades are more likely to embrace regionalism of the origin of batik makers. The development of Coastal Batik is different from the Royal Batik, this is caused from coastal Batik makers are not orphaned in customs and patterns of the royal batik motifs so that the motif that is generated are freer and adapted from the surrounding nature (flora and fauna) of the batik makers' area. For coastal society, in addition to being merchandised, batik is also an expression of the makers (Ratyaningrum, 2005). Batik clothing functioned as an identity marker; people could 'read' from the type and the colours and motifs of other peoples' clothes what town and social class they came from.

The aimed of this paper is to describe the motif of Dutch Batik in the colonial era and to analyze the role of the government and the Dutch merchant. The government was the ruler in that era who had a big role in developing the Batik in the Dutch Community. The Dutch merchant also designed and sold the Batik among their community.

\section{METHOD}

Research approach implemented here was literature method which was based on printed data. Printed data were collected from journals, and books, another data were collected from the internet. Furthermore, the documentary materials which was analyzed by using content analysis (Khotari, 2004, p. 110) based on Talcott Parsons' theory, The Functional Structure. Based on the Parsons' theory, individual was an actor in social system. He can be role as what society needs (Ritzer, 2012, p. 125). The role theory has focused on the characteristic behaviors of persons who occupy social positions within a stable social system (Biddle, 1986, p. 70). In this research the individual that had a big role in the development of the Dutch Batik was the merchant who was Dutch descent and the governor who ruled in the colonial era.

\section{RESULT AND DISCUSSION}

\section{Dutch Batik Motifs}

According to Veldehuisen (1993, p. 40) there are some Dutch batik type which was designed by the Indo-Europeans. This batik still has a Dutch taste which is shown on the ornaments of their works. The motifs are:

The motifs that are shown most are buketan. Buketan is the floral motif. This motif was inspired by the European Magazine at that time.

Batik Fairytale was inspired by European fairytale such as: mermaid, Roodkapje (the red hood) and the wolf. The red hood and the wolf are shown implicitly on the batik cloth. The buketan motifs are still shown.

Batik Wayang. Wayang as the Javanese identity was still being held and applied in the Dutch Batik motifs. One of the 
sarongs in the Rotterdam Museum has wayang figure alternated with birds and long hair dog.

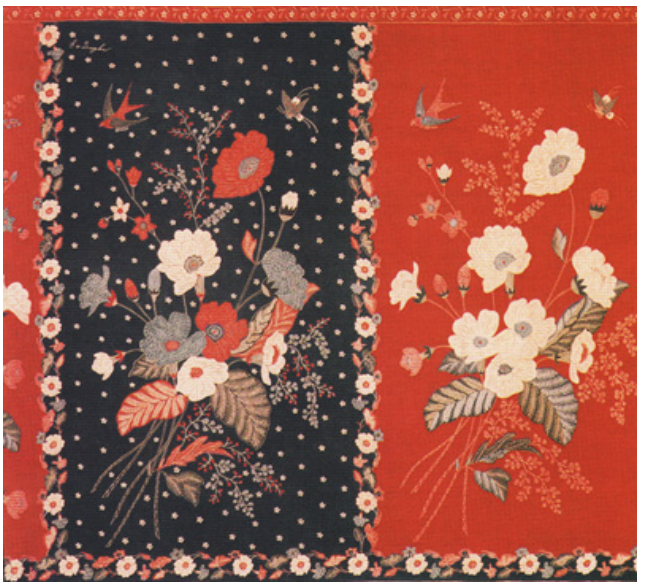

Figure 1. Buketan batik motif

(Source: http:/ / artscraftindonesia.com)

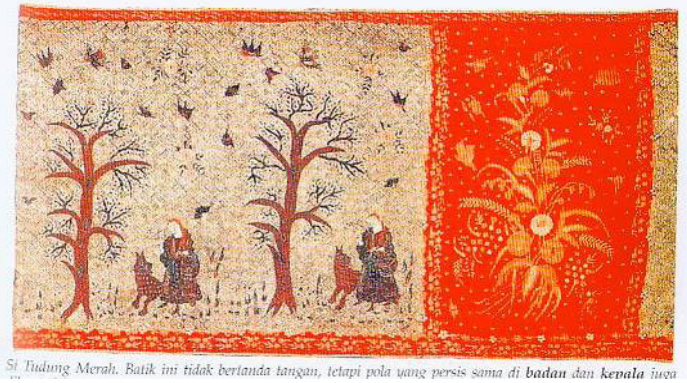

Figure 2. The Red Hood and the Wolf fairy tale batik motif (Source: Veldhuisen, 1993, p. 41)

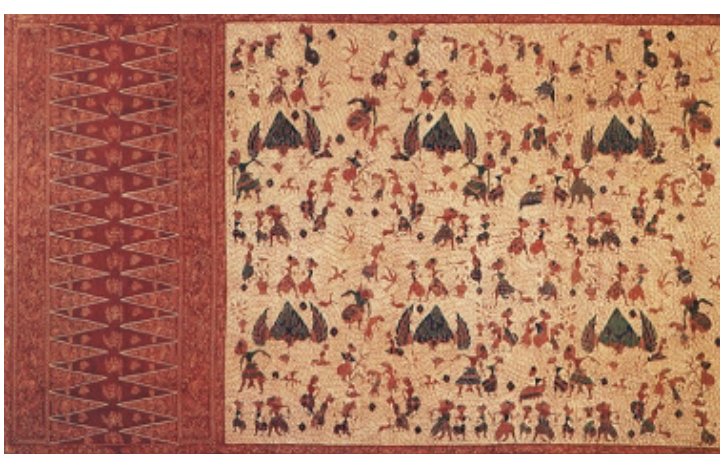

Figure 3. Batik Wayang

(Source: Dartel, 2005, p. 25)

Batik Poem. The poem is sometimes depicted on batiks. The poem was written along with the border around the cloth. In the middle of the cloth, there are some motifs that are not connected into the poem.

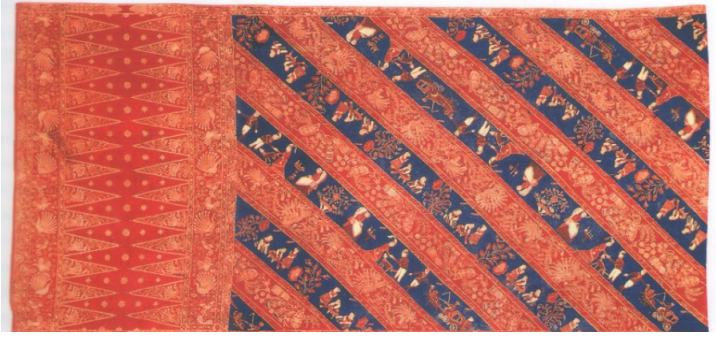

Figure 4. Batik Poem

(Source: Veldhuisen, 1993, p. 43)

Batik Perang Jawa and Perang Lombok. This motif refers to Java War (Perang Jawa) and Lombok War (Perang Lombok). The battle of Diponegoro against Dutch East Indies Army on Java. The Perang Lombok motifs is the copy of the Perang Jawa motif.
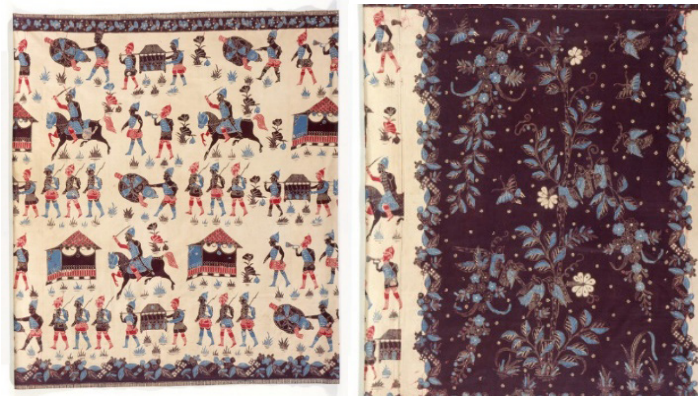

Figure 5. Batik Perang Jawa and Perang Lombok (Source: http:/ / collections.lacma. org)

\section{The Role of Dutch Descent}

Structural Role Theory as a macro view of social structure then in it there are subsystems that explain the social structure of the macro. Thus, it will be understood the nature and essence of the social behavior of particles is an individual to explain the social structure as a whole. Each individual whose role is described in the role and the role of the analysis (Kaplan \& Manners, 2002, p. 149). The role of individual entrepreneurs who can influence the design and production of Batik Netherlands explained using the theory of the role of structure. Individuals who appear to explain his contribution to the Dutch batik.

Cultural symbols associated with the system to be a reference and guide to community life and as a symbol of a system of 
meaning is transmitted through symbolic codes. So the notion of culture is an expression of the community in the form of ideas and human behavior in the community (Rohidi 2000 in Dharsono, 2007, p. 24). The mixing culture between local (Indonesian) and European characteristics, but not a mixed ethnicity, were created. Men started to live with their housekeepers and were soon influenced by them in all aspects of life, from food and interior design to clothing, language and ideas about raising children. (Dartel, 2005, p. 15). Furthermore, Dutch Batik is a form of expression of ideas and behavior of Dutch descent in Indonesia. They express all the West western poured in applied motives.

A Most Dutch Batik entrepreneurs are Java-born and the descendants of influential people or officers stationed in Java. Their Fathers or grandfather was Dutch soldiers or civil servants (the Netherlands) which were then married to the Dutch and reproduced in Java. The descent was also continuing the batik business. Reaching its peak of creativity in 1890-1910, Dutch Batik is clearly recognized through various works of arts named after the great designers. In the era of 1840-1860, for example, in Semarang there were only two Indo-European women who produced batik, namely Carolina Josephina von Franquemont and Carolina Catharina van Oosterom.

Miss Carolina Josephina Von Franquemont (1817-1867) was the first known Indo-European who acknowledged as batik manufacturer. She was the granddaughter of a military officer that was on duty in Batavia. Because of the political situation at that time, her grandfather had changed into a merchant so was his father. Her grandfather moved to Surabaya in 1825 then ten years later his father came to Surabaya. Caroline came to Surabaya also and open her first batik manufactory in 1840 at the age of twenty-three. But five years later she moved to Semarang because she wanted to be closer with her most important costumers. This way she could monitor any changes in her customers' preferences Caroline never married. She must have decided not to get married so that she could enjoy developing her passion into Batik. (Veldehuisen, 1993, p. 39).

Her moving to Semarang was the strongest reason of Carolina to develop her batik business because Semarang was the city in the coastal area that was developing. Her business instincts were from her father and her grandfather who were merchants. In Semarang many Indo-Chinese and Indo-European lived who became her target market.

Other Indo-European who acknowledged as a batik manufacturer was Mrs. Catharina Carolina Van Oosterom. Her father was a salt seller in the district of Semarang. She had loved Batik before she was married. She loved to wear sarong and kebaya during the Dutch Club events. At the age of 16, he was married in the 34 years old W.J. Van Oosterom. After his husband died, he left Catharina a small government pension which was not enough to live on. Thus, she sought a source of income and, around 1845, she opened her batik manufactory on Mt. Ungaran. It was around that time that Miss. Von Franquemont settled there also (Veldehuisen, 1993, p. 47)

Both Indo-European women have similarities in ornaments and motifs, it can be said that both of them were looking at each other. At that time this kind of cheating was pleasant, but then the motifs or the ornaments were developed little bit different. The richer multicolored cloth had been imported in North Coast. This color trend is about the Javanese aristocratic taste who liked the darker color. The North Coast batik is influenced by the Indian and Chinese. The European batik manufacturer fulfilled the market of the North Coast market who many Chinese and Indian lived there.

Some of the Europeans that came with Java had an aristocratic background, but they went to Java to make a fortune. And if they had an aristocratic background, they were sent to Indonesia because they had soiled the family name in the Netherlands. They were just common people who got a letter to a connection in 
the "high circles" in Batavia (Veldehuisen, 1993, p. 40).

Another contribution of the entrepreneur is in the style of decoration and composition that create a distinctive style of Pekalongan. The first style is characterized by simple lines and neat geometrical motifs. The second style is the use of motifs bouquet of flowers, or better known as buketan which is then regarded as the essence of the Coastal batik. This large bouquet placed in the body and head cloth. (Heringga, 2000, p. 50)

The Indo-European women chose a floral motif which was the typical of Europe in every season to represent each stage of their life. Flower color also determined who the wearer. White color for brides, blue for unmarried women, red depicts the love that used to married women, while purple was considered to represent the simplicity that was for the widows.

The acceptance of this Dutch motif by most coastal communities (Semarang and Pekalongan) due to the nature of coastal communities more open, free and dynamic whose livelihood rests on the sea (Gustami, 2007, p. 233). So the people of these two cities could accept the changes that were occurring at that time.

The North coast of Java was the developed trading area (Gustami, 2007, p. 183). The area spreads along from the Batavia (now Jakarta) up to Surabaya, according to Semarang which is on the North Coast of Java. The Indo-European Batik traders chose the Semarang city as the place of their factories because at that time Semarang was the biggest trading city that had big potential buyers and it was a habit to spend money easily. On the other hand, in Semarang, there were many experienced batik makers that were capable of increasing the batik production (Veldehuisen, 2007, p. 40).

\section{The Role of Dutch Rulers}

One of the basic problems in life is that determines the value orientation of human culture, Kluckhohn (Koentjaningrat, 2009, p. 156) mentioned that the existence of human nature relates to other human beings or others. Humans are very concerned with the vertical relationship fellows. In human life will be guided by the figures, leaders, senior, or boss. Moreover, the theory of the human concept, the development of Dutch batik will also be influenced by important figures or even a ruler. The power leader or leaders influence subordinates to participate in developing the Dutch batik. As role models that are considered less usual will be familiar if that wears on a figure or leader.

This anthropological study also borrowed a sociological theory, namely: Karl Marx theory known as the theory of Marxism dissected the power is about capitalism in the development of Dutch batik. The basic theory is that productive human being, that means to survive humans working in and with nature to produce food, clothing, and as the defense of life. In the survival of the human needs of help and cooperative with others.

The development of that cooperation, initially work in harmony, then becomes harmonious, which rise the capitalism. The owner of the capital ruled against subordinates (who did not have the capital). It showed the sense of power to oppress each other in order to develop the capital and its business (Ritzer \& Goodman, 2004, p. 31). Understand this was used in Netherlands in developing a business as the spread of capitalism in the colonies, Indonesia. The Dutch in addition developed the strength of capitalism in all facets of life, including in the development of culture, one of them was Dutch Batik. With sufficient capital, entrepreneurs set up businesses IndoDutch Batik and Batik motif design a new suit every taste and culture. The development of Dutch Batik also encouraged by the involvement of officials or influential people who had power.

One culture shift can be observed in Batik motif. Batik as a cultural artifact (Koentjanigrat, 2009, p. 146) or the results of the taste, creativity, made in Indonesia reproducible design motif just because of the ruling taste. Javanese traditional motifs 
previously have been standardized and applied for centuries converted into motive easily adapted to the tastes of the market. No more provisions against certain motives are forbidden from use, this Dutch Batik is used by anyone who can afford it.

For the Dutch women, Batik cloth was worn as long or sarong and kebaya or loose white tops and stylish tunic with lace. While men also wore gloves and long-sleeved tops are also white. This cloth was usually worn an informal or everyday clothes and it became favorite clothing Indo-European people because according to the tropical climate (Heringga, 2000, p. 27).

According to Coser (1975), a role can be defined as a social position, behavior associated with a social position, or a typical behavior. Some theorists have put forward the idea that roles are essentially expectations about how an individual ought to behave in a given situation, while others consider it means how individuals actually behave in a given social position (Şeşen, 2016, p.139)

A person who had an influence was the Governor General Daendels (18081811). He ruled the Indies in a fairly short time (approximately 3.5 years). He liked to combine cotton gloves and long-sleeved shirts as in informal event and also to the office (Heringga, 2000, p. 53). Indirectly, this Daendles habit affected the subordinates of the Dutch or other European to wear Batik and adapt to the climate and culture of Java. Local clothing comfort due to the climate in Java, which tend to be hot and humid, quite different in the Netherlands.

Hunter and McClelland stated that the functionalist focused on the individual, with the intent to show, although individual behavior is molded by broader social forces, but individual actors were still the decision-makers (Ferguson, 2013, p. 34).

The power of a ruler (Deandles) accelerated the change to a culture of people underneath him by how he dressed. Clearly, habits will be followed by the authorities under it either directly or indirectly appropriate. Repression by the authorities does not prohibit their adjustment to the culture of dress worn with its colonial occupiers, although the motives and different models

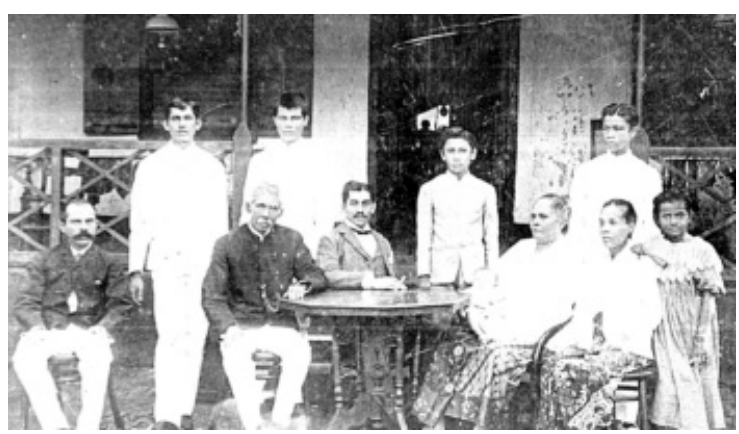

Figure 6. The Dutch was wearing sarong and white shirt (Source: https://batikplatform.com)

\section{CONCLUSIONS}

Dutch batik refers to the works of batik made in the batik industry that belongs to the Indo-European business women. The Batik can be recognized by its European motif patterns. One of the most famous is floral motif called buketan. Batik firms are already commercial purposes which are traded. It is contrasted into the original Java Batik which aims for his own use. The power of the ruler (Deandles) is to accelerate the changing of the culture of the people underneath by the way they dressed. The ruler wore batik every event either formal or casual as the example for his staff was to follow wearing batik so it accelerated the development of batik.

Dutch Batik is a form of expression of ideas and behavior of Dutch descent in Indonesia. It expresses all the West western poured in the motives. The women entrepreneurs were not classified as upper class, but the middle classes with high employee profession Dutch government. There was also a class of wealthy merchants. Just because the economic turbulence, the wealthy merchants were bankrupted. While the government employee only got a pension which was very less. This triggered the women must support her family, by opening a business Batik in their house and hiring people around. The Batik motives were got 
shift experienced hues due to the influence of the arrival of Dutch culture and the target market.

\section{REFERENCES}

Belting, H. (2003). Toward an Anthropology of the Image in Anthropologies of Arts. Massachusetts: Clark Studies In The Visual Arts.

Biddle, B. J. (1986). Recent developments in role theory. Annual Review of Sociology, 12(1), 67-92.

Dartel, D. V. (2005). Bulletin 369 Tropenmuseum Exploring Dutch Colonial Culture Through The Study of Batik. Amsterdam: KIT Publishers.

Dharsono. (2007). Budaya Nusantara. Bandung: Rekayasa Sains.

Djumena, N. S. (1990). Ungakapan Sehelai Batik (Its Mystery and Meaning). Bandung: Djambatan.

Ferguson, S. (2013). Mapping the Social Landscape: Readings in Sociology, 7th Edition. New York: McGraw Hill.

Gustami. (2007). Butir-Butir Mutiara Estetika Timur. Yogyakata: Prasisita.

Heringa, R. (2000). The fabric of Enchantment, Batik from the North Coast of Java. Los Angles: Los Angles County Museum of Arts.
Kaplan, D. \& Manners, R. A. (2002). Teori Budaya. Yogyakarta: Pustaka Pelajar.

Khotari. (2004). Methology: Method and Techniques. India: New Age International $(\mathrm{P})$ Limited Publisher.

Koentjaningrat. (2009). Pengantar Ilmu Anthropologi. Jakarta: Rineka Cipta.

Ritzer, George \& Goodman, D. J. (2005) Teori Sosiologi Modern. Jakarta: Prenada Media.

Setiawan, D. (2015). Jogja Fashion Week Carnival Costume in The Context of Locality. Harmonia: Journal of Arts Research and Education, 15(2), 126-132.

Susanto, M. (2002). Diksi Rupa, Kumpulan Istilah Seni Rupa. Yogyakarta: Kanisius.

Ratyaningrum, F. (2004). Bahan Ajar Kriya Tekstil. Surabaya: UNESA Press.

Roojen, P. V. (1998). Batik Design. Amsterdam: The Pepin Press.

Şeşen, E. (2015). Role Theory and Its Usefulness In Public Relations. European Journal of Business And Social Sciences, 4(1), 136-143.

Veldehuisen, H. C. (1993). Batik Belanda 1840-1940, Dutch Influence in Batik from Java History and Stories. Jakarta: Gaya Favorit Press.

Wardhani, C. K. \& Panggabean, R. (2004). Tekstil. Jakarta: Desantara Utama. 